\title{
The Effect of Electronic Commerce on the Accounting Information System of Jordanian Banks
}

\author{
Adel M Qatawneh \\ Department of Accounting, Al-Zaytoonah University of Jordan, Amman, Jordan \\ Tel: 962-79-517-1716 E-mail: a.qatawneh@zuj.edu.jo
}

Received: February 19, 2012

Accepted: March 12, 2012

Published: May 1, 2012

doi:10.5539/ibr.v5n5p158

URL: http://dx.doi.org/10.5539/ibr.v5n5p158

\begin{abstract}
This study aimed to determine the effect of electronic commerce (e-commerce) on Accounting Information System (AIS) in Jordanian banks. The study importance arises from the need to recognize e-commerce and AIS as the greatest development in the world of business, the variables that will be affected by e-commerce are: reliability of AIS on the bank, the operational performance, cost of reduction, customer services. To achieve the objectives of the study a questionnaire was designed and distributed to the society of the Jordanian bank sector. The data analysis found out that the banks in Jordan have positive impact towards information technology they agree on the benefit of e-commerce and what customer can get from it. The statistical analysis showed that e-commerce had a positive impact on the AIS and that e-commerce has a significantly statistical relationship with AIS itself, AIS development, cost reduction aspect in the AIS of the bank, the aspect of improving the operational performance of the bank's AIS and finally with the customer service.
\end{abstract}

Keywords: Electronic commerce, Accounting, Jordanian bank

\section{Introduction}

At the turn of the century, the world has witnessed a revolution in the field of information technology, information technology has become on indispensable factor and a real necessity for achieving success for establishments in all sectors.

Establishment has become more aware of the strategic role played by information technology in general and the accounting information system in particular in achieving a competitive outstanding quality.

Hence, this study is to highlight the importance of the importance of the Electronic Commerce on the Accounting Information System of Jordanian Banks.

Turbanet al. (2010) defined e-commerce as the process of buying, selling, transferring, or exchanging products, services, and/or information via computer networks, mostly the internet and intranets. They also indicated that e-commerce is a part of a broader definitionwhich is referred to as e-business; it includes not just buying and selling but also servicing customers collaborating with business partners, and conducting electronic transactions within the organization.

Accounting information system (AIS) is a subsystem of the management information system (MIS) that processes financial transactions to provide (1) internal reporting to managers to be used in planning and controlling current and future operations and for non-routine decision making, (2) external reporting to outside parties such as to stockholders, creditors, and government agencies. Romney and Steinbart (2012) indicated that the accounting is the language of business and that the AIS are the intelligence of that language.

These days the world is becoming more competitive due to the information technology growth. Day by day the demand for companies to improve themselves and try to keep up with the rapid changes while continuing to guarantee the quality of their product and services is increasing.

Information technology has had as much impact on our Jordanian society as the separate sectors working in it. Therefore the world is becoming more competitive with all of these computers and other electronic devices which ease the communication between the company and its customers. A variety of networks such as internet are used as our main mean of information exchange.

Information technology changes have forced different companies to redefine their existing business activities to moderate themselves. Therefore companies need a good information system which enables efficient and effective use of information to gain competitive advantages. 


\section{Study Problems}

Due to the lack of researches addressing the effect of e-commerce on improving AIS of banks particularly in Jordan, this study attempts to answer the following questions:

1. What is the effect of e-commerce on the AIS?

2. What is the effect of e-commerce on the AIS development?

3. What is the effect of e-commerce on the reliability of AIS?

4. What is the effect of e-commerce on the AIS from the perspective of cost reduction?

5. What is the effect of e-commerce on the AIS from the perspective of improvement in the operational performance of bank?

6. How does e-commerce affect the AIS customer service?

\section{Study Objectives}

1. To identify the concept of e-commerce and AIS.

2. To examine the relationship between the reliability and confidentially of AIS and e-commerce in Jordanian banks.

3. To examine the relationship between the ability of saving cost through AIS and e-commerce in Jordanian banks.

4. To examine the ability to improve the operational performance of Jordanian banks.

5. To examine the ability to improve the customer services of Jordanian banks.

\section{Methodology}

The population of the study includes all banks located in Jordan. The study included the financial managers working in the 32 banks In order to achieve the objectives of the study. The methodology is as follows:

1. Concluding exploratory study.

2. Developing thesis proposal as the primary model of the thesis.

3. Developing the questionnaire.

4. Collecting data through the questionnaire and other data collection method.

5. Carrying out a statistical analysis.

6. Developing the final form of the study.

7. Writing up the conclusion and recommendations.

\section{Hypotheses}

1. $\mathrm{H}_{1}$ : there is a statistical significant relationship between e-commerce and AIS development in banks.

2. $\mathrm{H}_{1}$ : there is a statistical significant relationship between reliability and confidentiality of the AIS of Jordanian banks and e-commerce.

3. $\mathrm{H}_{1}$ : there is a statistical significant relationship between the ability to save cost through AIS and e-commerce in Jordanian banks.

4. $\mathrm{H}_{1}$ : there is a statistical significant relationship between the ability to improve operational performance of Jordanian banks through AIS and e-commerce.

5. $\mathrm{H}_{1}$ : there is a statistical significant relationship between the ability to improve customer services through AIS and e-commerce in Jordanian banks.

\section{Literature Review}

Due to the novelty of this subject the researchers found few studies regarding the impact of e-commerce on the accounting information system of the bank in Jordan. Also it should be noted that almost all the studies found addressed the subject of the impact of e-commerce on the AIS in a general way.

Al-Qudah (2011) conducted a study to investigate the impact of accounting information systems on the effectiveness of internal control in Jordanian commercial banks. The study concluded that AIS have an impact on the effectiveness of accounting control in Jordanian banks particularly that the AIS helps generate accurate, up to date, comprehensive and comparable data. Moreover, there is a positive effect of AIS on the effectiveness of management control at Jordanian banks in that the data produced by the AIS helps decision makers to make operational and strategic decisions. 
Another study was conducted by Obaid $(2005,2006)$ which concluded the following results:

1) Most of the commercial governmental banks in Jordan had its own website on the internet and the conduct some of their business online but with different degrees.

2) The year 2005, was known for the increasing numbers of commercial, investment banks, and the branches of the foreign banks which has websites that electronically disclose their annual and periodic financial statement.

3) There is a significant relationship between the size of the bank and the e-commerce application.

4) There is a significant relationship between the hierarchies of the possession andthe work nature of the bank with the application of e-commerce in the internet banking services.

Saleh (2005) conducted a study about electronic commerce which had the following results:

1. E-commerce is one of the reasons that the rates of trading are rising.

2. E-commerce helps in the growth of the internal and external trade.

3. There is an effect of meeting the requirements of e-commerce on the usage of e-commerce.

4. There is an effect of the security on the web on the increased usage of e-commerce.

Choe (1996), the study highlight the importance of the relationships among performance of accounting information systems, the result showed that the use of information system a statistically significant influence on the performance for the firms.

The study concluded the following results:

1) There is a significant relationship between the size of the firm and the AIS application.

2) There is a significant relationship between the ability for the employees and the AIS applications.

\section{Results Analysis}

Table 1 shows that $40.63 \%$ of the managers in the society of the study are females and $59.37 \%$ are males.

Insert Table 1 Here

Table 2 shows that $9.37 \%$ of the managers working in the banking sector are between the ages of 20 and $29,40.63 \%$ are between the ages of $30-39,43.75 \%$ are between the ages of $40-49$ and finally $6.25 \%$ are 50 years old or above.

Insert Table 2 Here

Table 3 shows that $6.25 \%$ of the society's qualification is diploma, $28.13 \%$ have bachelor's degree, $46.87 \%$ have master's degree and $15.63 \%$ have $\mathrm{PhD}$.

Insert Table 3 Here

Table 4 shows that $3.13 \%$ of the society of the study majored in AIS, $34.37 \%$ majored in MIS, $12.5 \%$ majored in BIS, $40.63 \%$ majored in accounting and $9.37 \%$ majored in finance.

Insert Table 4 Here

Table 5 shows that $6.25 \%$ of the society has an experience of less than 5 years in bank management, $41.25 \%$ have 5 to 10 years, and $62.5 \%$ have an experience of more than 10 years.

Insert Table 5 Here

\section{Testing the Hypotheses}

\subsection{First Hypothesis}

There is a statistical significant relationship between e-commerce and AIS development in Jordanian banks.

For testing this hypothesis F- test was done using SPSS and the following results were calculated:

The correlation value $=0.23$ between the e-commerce and AIS development, and the correlation is statistically significant, therefore we accept the $\mathrm{H}_{1}$ hypothesis which states that there is a relationship between e-commerce and AIS development in banks.

\subsection{Second Hypothesis}

There is a statistical significant relationship between reliability and confidentiality of the AIS of Jordanian banks and e-commerce.

For testing this hypothesis F- test was done using SPSS and the following results were calculated: 
The correlation value $=0.56$ between the e-commerce and AIS, and the correlation is statistically significant; therefore we accept the $\mathrm{H}_{1}$ hypothesis which states that there is a relationship between e-commerce and AIS in banks.

\subsection{Third Hypothesis}

There is a statistical significant relationship between the ability to save cost through AIS and e-commerce in Jordanian banks.

For testing this hypothesis F- test was done using SPSS and the following results were calculated:

The correlation value $=0.44$ between the e-commerce and the ability to save cost through AIS in Jordanian banks, and the correlation is statistically significant, therefore we accept the $\mathrm{H}_{1}$ hypothesis which states that and there is a relationship between e-commerce and the ability to save cost through AIS in Jordanian banks.

\subsection{Forth Hypothesis}

There is a statistical significant relationship between the ability to improve operational performance of Jordanian banks through AIS and e-commerce.

For testing this hypothesis F- test was done using SPSS and the following results were calculated:

From the table above the correlation value $=0.37$ between the e-commerce and the ability to improve operational performance of Jordanian banks through AIS, and the correlation is statistically significant, therefore we accept the $\mathrm{H}_{1}$ hypothesis which states that there is a relationship between e-commerce and the ability to improve operational performance of Jordanian banks through AIS.

\subsection{Fifth Hypothesis}

There is a statistical significant relationship between the ability to improve customer services through AIS and e-commerce in Jordanian banks.

For testing this hypothesis F- test was done using SPSS and the following results were calculated:

The correlation value $=0.42$ between the e-commerce and the ability to improve customer services through AIS in Jordanian banks, and the correlation is statistically significant, therefore we accept the $\mathrm{H}_{1}$ hypothesis which states that there is a relationship between e-commerce and the ability to improve customer services through AIS in Jordanian banks.

\section{Conclusions}

This study concluded the following:

1. Electronic commerce had a statistically significant influence on the accounting information systems development of Jordanian banks. The results also showed statistically significant between electronic commerce and reliability of the accounting information systems in Jordanian banks, the Impact of electronic commerce has enhanced the reliability which represents one of the qualitative characteristics of accounting information by improving the ability to deal with the data for banks, reduce errors, verification of data, security and protection.

2. Electronic commerce had a statistically significant influence for ability to reduce cost, improve operational performance of Jordanian banks through accounting information systems.

3. The use of Electronic commerce in the accounting information systems for Jordanian commercial banks contributed to the improvement of services provided to the clients.

4. Electronic commerce had contributed to increase efficiency and effectiveness of accounting information systems in Jordanian banks.

\section{Recommendations}

The study recommends the following:

1. It is necessary for Jordanian banks to invest in the advancement of the information technology especially with regards to aspects related for electronic commerce in order to keep up with the spirit of the age and improve the effectiveness and efficiency of the Accounting Information System.

2. Jordanian banks shall increase training courses in electronic commerce for accountants in order to provide their establishments with a specialized staff ready and qualified to face the challenges and to solve the problems imposed by the Information Technology development.

3. Continued follow-up the latest developments in information technology in order to benefits from the services offered by using electronic commerce for clients in Jordanian banks. 
4. Study other sectors except banking sector to identify the extent of use electronic commerce in accounting information systems in those sectors.

5. It also recommends that Conducting more studies concerning the conceptual framework for both electronic commerce and accounting information system and their impact on each other.

\section{References}

AICPA/CICA. (2004). Privacy frame work including the AICPA/CICA trust service privacy principles and criteria, issued by the assurance services executive committee of the AICPA and the assurance services development board of the CICA.

Al-qudah, G. (2011). The impact of accounting information systems on the effectiveness of the internal control in jordanian banks, electronic version. Interdisciplinary Journal of Contemporary Research In Business, 2(9), 365-377.

Barczak, G., Sultan, F., \& Hultink, E. J. (2007). Determinants of IT usage and new product performance. The Journal of Product Innovation Management, 24(6), 600-613. http://dx.doi.org/10.1111/j.1540-5885.2007.00274.x

Choe, J. M. (1996). The relationships among performance of accounting information systems. Journal of computer information systems, 12(4).

Davenport, T. H. (1998). Putting the enterprise into the enterprise system. Harvard business review, 76(4), 121-131.

Howell, J. M., \& Higgins, C. A. (1990). Champions of technological innovation. Administrative Science Quarterly, 35, 317-341. http://dx.doi.org/10.2307/2393393

Lymer, A., \& Debreceny, R. (2003). The Auditor and corporate reporting on the internet: challenges and institutional responses. International journal of auditing, 7, 103-120. http://dx.doi.org/10.1111/1099-1123.00063

Misic, M., M. Hill, J. A. (1998). The impact of networks on the systems development. Journal of computer information system, 39(1).

Purwadi, P. (2008). Advantages of web services in E-Business, A large scale empirical study. Working paper. MIT sloan school pf management.

Romney, M. B., \& Steinbart, P. J. (2012). Accounting information system. New Jersey: Prentice Hall.

Shore, B. (1996). Using information technology to achieve competitive advantage. Journal of computer information systems, 36(4), 14-20.

Turban, E., King, D., Lee, J., Liang, T., \& Turban, D. C. (2010). Electronic Commerce a Managerial Perspective. New Jersey: Prentice Hall.

Whelan, E. (2007). Exploring knowledge exchange in electronic networks of practice. Journal of Information Technology, 22(1), 5-12. http://dx.doi.org/10.1057/palgrave.jit.2000089

Zikmund, W. G. (2003). Business research methods (7th ed.). Thomas south-western.

Table 1. The relative distribution by gender

\begin{tabular}{lll}
\hline Gender & Frequency & Percentage \\
\hline Female & 13 & $40.63 \%$ \\
Male & 19 & $59.37 \%$ \\
Total & 32 & $100 \%$ \\
\hline
\end{tabular}

Table 2 . The relative distribution by age

\begin{tabular}{lll}
\hline Age & Frequency & Percentage \\
\hline $20-29$ years & 3 & $9.37 \%$ \\
$30-39$ years & 13 & $40.63 \%$ \\
$40-49$ years & 14 & $43.75 \%$ \\
50 years and above & 2 & $6.25 \%$ \\
Total & 32 & $100 \%$ \\
\hline
\end{tabular}


Table 3. The relative distribution by educational qualification

\begin{tabular}{lll}
\hline Qualification degree & Frequency & Percentage \\
\hline Diploma & 2 & $6.25 \%$ \\
Bachelor & 9 & $28.13 \%$ \\
Master & 15 & $46.87 \%$ \\
PhD & 5 & $15.63 \%$ \\
Other & 1 & $3.12 \%$ \\
Total & 32 & $100 \%$ \\
\hline
\end{tabular}

Table 4 . The relative distribution by major

\begin{tabular}{lll}
\hline Major & Frequency & Percentage \\
\hline Accounting Information System & 1 & $3.13 \%$ \\
Management Information System & 11 & $34.37 \%$ \\
Business Information System & 4 & $12.5 \%$ \\
Accounting & 13 & $40.63 \%$ \\
Finance & 3 & $9.37 \%$ \\
Total & 32 & $100 \%$ \\
\hline
\end{tabular}

Table 5. The relative distribution by years of experience

\begin{tabular}{lll}
\hline Experiences years & Frequency & Percentage \\
\hline Less than 5 years & 2 & $6.25 \%$ \\
$5-10$ years & 10 & $41.25 \%$ \\
More than 10 years & 20 & $62.50 \%$ \\
Total & 32 & $100 \%$ \\
\hline
\end{tabular}

